\title{
A blasfêmia, o prazer, o incorreto
}

\author{
Beth Lopes
}

Deus é um grande artista, fez o Himalaia. Como Deus não poderia ter filho, criou gente como vocês. Vocês são filhos do demônio, vão para o gueto, e nós não queremos mais ver vocês. Vão para o pântano ou para a floresta. E eles pensaram: Filhos do demônio... Não é tão mau. $O$ demônio deu liberdade para a mulher... Para a primeira mulher, Eva. A mulher, então, foi o primeiro bufäo. $-\mathrm{Na}$ Bíblia vocês podem ver o que Deus disse à mulher quando ela comeu a maçã - e completa a idéia final: Vão para o gueto! (Gaulier, 1999).

\section{0 riso blasfemo}

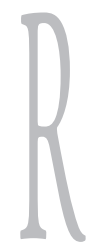

imos por diversas razões; rimos para demonstrar alegria; rimos de satisfação, de felicidade, de alívio. Rir dá uma sensação de liberdade, uma sensação real de que, por alguns instantes, os problemas do cotidiano deixam de existir.

Este momento fica marcado em nossa memória, sempre associado a um instante de prazer. Contudo, antes de ser uma satisfação física, é um procedimento lógico de apreensão da realidade, onde o riso é o aviso sonoro - de aprovação, é claro. Rimos porque estamos nos divertindo com algo que reconhecemos e que nos permite fazer inúmeras analogias.

Com essas emoções que nos desobstruem, não menos sérias do que aquelas que nos entristecem, provocando o choro, conseguimos perceber o fundo de nossas contradiçóes. Rir do jeito dos outros, da exuberância dos tipos humanos, da sua semelhança com os animais, dos costumes diferentes. Rir de maneira discreta, passando por inúmeras gradações que chegam à gargalhada, o que significa, no fim de tudo, rir de nós mesmos.

Quando rimos de algo, ou de alguém, no fundo estamos negando-os. Rimos do que é considerado falho, incorreto, proibido. A negação é feita para poder afirmar um outro comportamento, ou uma outra idéia, que consideramos correta. $\mathrm{Ou}$, ainda, talvez, para reafirmar a verdade encoberta.

O riso, como nos mostra Bergson, é uma manifestação que delimita fronteira cultural. E tal fato nos leva à constatação de que temos a capacidade de reconhecer códigos comportamentais comuns, os quais são regidos por uma lógica ao mesmo tempo silenciosa e potente.

Mas não rimos somente do que é "menor". Podemos rir também da astúcia e de refinada construção da inteligência. Rimos da 
ironia. E, neste sentido, o jogo muda as regras. $\mathrm{O}$ sujeito que manifesta o riso não é mais aquele que, com segurança, constata a sua superioridade lógica e existencial. Neste caso, rir é resultante do reconhecimento de algo que não havíamos percebido sobre nós mesmos, e ao mesmo tempo nos coloca como portadores de defeitos e imperfeições. Desta vez, nós somos o objeto do qual se deve rir.

Seja o que for que queiramos negar ou afirmar, isto se esconde atrás do riso evocado pelos Bufōes. A seu modo, eles testemunham a condição humana no espelho retorcido da derrisão e carregam em seus corpos excêntricos os motivos risíveis que perduram através dos tempos e das culturas.

Bufão, Truão, Bobo, Histrião, Momo, Charlatão, Fanfarrão; não importa o nome, o que se sabe é que é um ator a quem, antigamente, se destinavam papéis de comicidade grosseira. O corpo deformado do Bufão confirma a relação que se faz dele com o mundo da imagem. Se tentarmos resgatá-lo em nossa memória, certamente encontraremos exemplos precisos em outras artes. $\mathrm{O}$ prazer da blasfêmia serviria de motivação não só para o teatro, mas também para a pintura de Bosch, de Brueguel, de Velásquez e de Goya. Na música ele reapareceria como um personagem central da ópera Rigoletto de Verdi. Estes exemplares demonstram a força da natureza visual da sua figura.

\section{0 percurso da blasfêmia}

Revendo as diferentes manifestaçôes do bufão presentes na história, podemos perceber, gradualmente, os inúmeros aspectos que fundamentam sua importância. Sem ter a pretensão de abarcá-lo aqui em toda a sua extensão, apon- tamos primeiramente uma espécie que, por não pertencer ao universo específico do teatro, inserimos entre os buföes míticos, representados nas festas e rituais que se associavam ao conceito de fertilidade e progresso. Estas figuras ressaltavam os aspectos monstruosos, ridículos e sexuais das potências sagradas para "desdramatizar a existência” (Clastres, 1986, p. 91).

Pertencem a esta categoria os bailarinos diabólicos, xamãs, sacerdotes e reis, que utilizavam a imitação burlesca, nas comunidades primitivas, para domesticar o riso pela via da ritualização (Macedo, 2000, p. 36). As figuras extraordinárias destas representações ridicularizantes, monstros, bruxas, anões, gigantes e loucos transpunham o imaginário popular, misturando os elementos satíricos com as situações sérias, alinhando valores opostos como o sagrado e o profano, vida e morte, representação e realidade.

Entre tantas outras figuras da legião mítica dos bufōes, temos no "trickster" 1 um antepassado importante do nosso personagem. Nascido nos confins da animalidade e da humanidade, suas aventuras são contadas em um ciclo de representações alegóricas de entidades burlescas. As descrições de tal personagem lembram que, além da sua aparência ambivalente, meio deus meio demônio, transformava-se em mulher ou em diferentes animais, envolvendo um travestimento não apenas físico, mas também espiritual. Esse ser paradoxal combina o bem e o mal em um vaivém fantástico, alternando em seu jogo grosseria sexual, astúcia, blasfêmia, alegria, provocaçôes, encantamento, crueldade e canibalismo. Esses atributos caracterizam-se como algumas das "incivilidades" que entram na sua composição e fazem dele um modelo de imaginação bufa na forma de parábola.

Nascidas da mesma espécie de brincadeiras populares, encontradas na cultura grega ar-

1 Segundo Jean Duvignau, em "Rire et Après", o "trickster" faz parte de um ciclo, saído da África, do Norte da América e da Oceania, composto de histórias humorísticas que contam aventuras deste personagem burlesco. 
caica, as epifanias ao deus Dioniso se assemelham. O deus do vinho, da embriaguez e do prazer, ao mesmo tempo sanguinário e cruel, é o protobufão - o primeiro representante do teatro que traz no conteúdo e na forma, no mito e na festa, não só a expressão inspiradora da tragédia, mas também a da comédia, da farsa e da bufonaria.

A dupla natureza de Dioniso, constituída que é por contrastes de caráter e de físico, reúne o prazer à dor, assim como a destruição à renovação, e o lamento à celebração. As contradições encontradas em suas ações e na sua personalidade são de ordem variada. Pode-se ver nele as duas faces, da excitação e da loucura, e a magia do deus. Nesta imagem encontra-se o paradigma da sua essência mística e de sua arte, segundo as críticas à moralidade e à linguagem feitas por Nietzsche. Fonte de pura desmedida é, ao mesmo tempo, substrato da medida do mundo apolíneo reunida na interioridade complexa e plural do mito de Dioniso.

Os vestígios deixados pelos bufôes míticos não precedem, no sentido cronológico, a presença dos bufōes domésticos (Gazeau, 1995, p. 11). Pelo visto, estes seriam presença incontestável nas festas e banquetes ao lado de soberanos até mesmo entre os povos primitivos. Segundo a história dos bufões contada por Gazeau, eles não se limitavam a fazer rir, mas também acumulavam a função do louco sábio, o morósofo. Assim, ele confundia sentenças morais com anedotas pueris, ou então, ações ridículas com uma profunda reflexão filosófica. Todo soberano teria um louco ou um parasitós $^{2}$ em sua mesa. Cabe recordar que um dos mais antigos e ilustres, com certeza, teria sido Esopo, o fabulista feio e tartamudo.

Mas sem dúvida, teria sido na Idade Média e Renascimento onde se veriam os bufóes em suas múltiplas formas, sobretudo os populares, os quais eram encontráveis por todas as partes: "jongleurs", 3 mimos, ventríloquos, equilibristas, malabaristas, titeriteiros, saltimbancos, menestréis. Nas sucessivas cortes, nos castelos entre os príncipes e reis, nos conventos e nas igrejas, junto a bispos e abades, sua função constituía-se em um título de ofício que nunca se deixava vago. Certamente o bufão era um requisito obrigatório de todas as comemorações. Fazendo apresentações nas casas, palácios, tavernas e outros lugares públicos, destaca-se a célebre figura do bobo da corte, cuja profissão se confundia com a de um servo. Além de servir, ele teria que "brilhar" distraindo os convidados, arremedando as atitudes do seu amo com ações, palavras e chocarrices.

Em certo momento da história o bufão parece ter desaparecido. O bobo do rei vai sumindo aos poucos das cortes medievais. Talvez, na sua forma anarquista, pelo menos, o bobo não iria mais invadir as naves das igrejas, nas datas religiosas especiais. Tampouco elegeria o rei de um mundo virado de cabeça para baixo. Um possível motivo pode ter sido a censura e o controle do riso que a Igreja passa a exercer quando a sociedade começa a se perceber a si mesma como ridícula. O movimento doutrinador da cristianização empreendido pela Contrareforma, parece ter sido o grande responsável pela domesticação do riso, o que implicou na morte das manifestações cômicas populares. Não se sabe ao certo, mas o bufão que emergia dos mundos subterrâneos da Idade Média talvez tenha sido perseguido pela Inquisição ou, quem sabe, não tenha sobrevivido ao novo pensamento da Renascença.

$\mathrm{Na}$ visão renascentista, o indivíduo vai adquirir valor, e Deus, então, não será visto mais como o centro do mundo, de acordo com o

2 Convidado, farsante, produtor de riso.

3 Artistas profissionais, que possuíam qualidades múltiplas, eram capazes de cantar, tocar, atuar, dançar, recitar e fazer acrobacias. 
espírito da Idade Média. O foco, neste período, torna-se o da valorização da consciência humana, onde o mundo é visto de modo relativizado. $\mathrm{O}$ teatro, nessa esteira, descobre a perspectiva tridimensional e, portanto, o palco ilusionista do qual herdamos a cena à italiana.

O bobo, por certo, poderia ser revisto no espetáculo popular, no circo, no teatro de variedades, no "vaudeville" e de outras maneiras que se disseminariam em meio aos truques e ao luxo das encenações do Renascimento, permanecendo até esta nossa época de forma significativa.

Diante da sofisticação das novas descobertas artísticas, o interesse pelo teatro clássico e pela arquitetura cênica, que florescem no período renascentista, torna possível que as formas populares sejam colocadas também a serviço desse novo teatro.

A "Commedia Dell'Arte" (também chamada de comédia "bufonesca"), que eclodiria nesta época e cujo êxito popular era incontestável, passaria das ruas para o palácio, tamanho era o interesse que despertava a originalidade do desempenho dos atores. A sua forma sempre ligada ao que existe de mais legítimo da arte teatral, a arte dos atores, assim mesmo retomaria o enredo da chamada comedia nova ${ }^{4}$ grega, entre outras fontes, - comédias antigas, pastorais e peças populares - evidentemente, bem ao gosto da classe média que prosperava no início dos tempos modernos.

Além disso, a falta da dimensão sagrada a que se contrapõe o ator bufo do período medieval, de certa maneira, teria esvaziado a sua função. Sem o teor blasfemo que o bufão possuía ao inverter a ordem cristã e todo poder dominante, o humor perdia a força crítica.

Mas a influência do bufão seria marcada em outras esferas, além dos modos de diversão do teatro popular, como resultante da fusão en- tre o popular e o erudito, tão peculiar neste período de transição para a Época Moderna. O bobo seria eternizado de modo fecundo, na incorporação de sua cultura à literatura, à pintura, à música e à dramaturgia.

A cultura dos bufóes no Renascimento iria ecoar, ainda, na literatura de Erasmo de Roterdam, com o Elogio da loucura, e de Rabelais, cuja obra serviu de investigação para a teoria de Mikhail Bakhtin sobre a cultura cômica popular que trouxe no centro da obra a figura do bufão. Na Espanha, com Miguel de Cervantes, teríamos as emblemáticas figuras tragicômicas de Dom Quixote e Sancho Pança, cuja dupla seria inspiradora para os palhaços, "clowns" e bufōes modernos.

O tema dos bufōes tornar-se-ia eterno, entretanto, na mão do mais famoso dos dramaturgos ingleses da renascença, Shakespeare. O autor celebrizaria esta figura bizarra em uma gama bem variada de aspectos. Bufōes sábios, mágicos, excêntricos, grotescos, selvagens, endiabrados, trapalhões, trapaceiros, bondosos, pérfidos, sombrios, falsos, bajuladores e oportunistas tornam-se os personagens tão sonhados pelos grandes atores.

\section{0 território do cômico-sério}

A visibilidade da bufonaria estaria definitivamente associada, de forma dantesca, ao inferno grotesco da cultura popular da idade Média e Renascimento. Os bobos, essas figuras recuperadas nos estudos sobre este período por Bakhtin, eram consagrados pela principal festa, a do carnaval. A síntese da ação carnavalesca, a da entronização-destronização, compreende toda espécie de ambigüidades. No centro das ambigüidades está aquela ação que personifica, na fi-

4 A comédia nova grega teria sido representada por Menandro, cujo tema diferenciava-se da comédia antiga, de Aristófanes, que criticava o cidadão como parte do Estado para ilustrar a vida cotidiana, a natureza privada do homem grego. 
gura do falso rei do carnaval, o duplo destronante. Ao final da festa, coroa-se o antípoda do rei, o bobo. Assim, parodiar é criar o duplo destronante.

A ação bufa, analisada por Bakhtin, é uma herança repassada pela cultura popular cômica à literatura, e pontualmente, observada por ele na obra de Rabelais e de Dostoiévski. Tal teoria torna-se fundamental para a compreensão das manifestações do grotesco nas formas teatrais, trazendo à superfície, no conjunto das reflexões, a estética dos bufōes.

O grotesco, como uma categoria estética que pressupõe uma comicidade degradante, como aquela presente nos participantes das festas carnavalescas, tem na sua concepção um enfoque corporal. A monstruosidade do corpo grotesco nos revela a relação entre forma interna e externa. A expressão alegórica deixa entrever uma visão de mundo na sua distorção física, moral e espiritual. O grotesco é um instrumento da crítica que acaba com tudo, mas como a existência é indissolúvel, cria situações desumanas. As imagens disformes dos corpos grotescos ressaltam, concretamente, a tal "segunda" natureza do homem. Associadas a uma linguagem marginal que não se manifestava nas solenidades oficiais, as imagens grotescas expressavam de modo fundamental a vida pela lógica do mundo invertido ou mésalliances, segundo Bakhtin.

Os elementos burlados pela inversão e, portanto, permitidos durante o carnaval, traziam no espírito da bufonaria momentos repletos de paganismo e licenciosidade. Remexiam com as relações de parentesco, alteravam o "status" social, homogeneizando diferenças e abolindo as hierarquias. E a profanação, principalmente dos papéis religiosos, girava em torno de três eixos: sexo, comida e poder.

A visão carnavalizada do mundo, para Bakhtin, é uma visão crítica da sociedade. Este olhar se realiza em função da eliminação das distâncias temporais e em favor de um tempo presente da "representação", bem como em relação à anulação das diferenças sociais entre os homens.
A sátira menipéia, o gênero dialogal que remonta ao folclore carnavalesco, traz o aumento do peso cômico, não se prende a qualquer exigência de verossimilhança, cria situações extraordinárias, cenas de escândalos e comportamento excêntrico, além de produzir situações de contrastes agudos com os jogos de oxímoros. Portanto, a representação "carnavalizada" contida na ação do ator traz uma qualidade paradoxal à atuação, na medida em que reúne em um mesmo corpo os contrários: o cômico ao sério, o risível ao grotesco, a ridicularização ao júbilo. Inspirados nas festas carnavalescas, o comportamento, o gesto e a palavra libertam-se da vida extracarnavalesca para "viver" uma vida derivada de sua ordem habitual. Desta forma, reforçase a idéia de representação como simulacro.

Duplicidade e inversões grotescas são, portanto, os mecanismos utilizados pelo bufão para empreender uma representação que o particulariza, que o distingui dos demais fazedores de riso. Com estes recursos o ator faz a paródia, a qual consiste na mais cruel arma de denúncia das vilezas humanas.

\section{A passagem da máscara à sala de espetáculo}

A máscara grotesca utilizada pelo ator popular se viu apropriada, em outros diferentes momentos, pela dramaturgia e encenação. Esta herança estética apresenta-se sob diferentes formas de máscaras que ela vai assumindo no curso da história, desde uma deformação ligeira, material, até uma mais radical.

Com todo o seu vigor o bufão volta ao espetáculo retomado pelos encenadores da esquerda vanguardista, do princípio do século $\mathrm{XX}$, num resgate da cultura do passado, do caráter popular da personagem e de todo o tipo de manifestação coletiva e duradoura como a do teatro oriental. Em busca da vivacidade e da sedução que eles exerciam no grande público, esse teatro valorizaria a teatralidade, o jogo, a festa e a espontaneidade do teatro popular cômico. 
O papel do grotesco seria resgatado na prática de Stanislavski, Meyerhold, Vakhtangov, Brecht e, de certa forma, Artaud também, ao lado das idéias que levaram, no conjunto, às reaçôes ao Naturalismo e ao teatro burguês. Para eles a máscara se impõe como símbolo do jogo do ator e o grotesco, sugerindo gestos exagerados e distantes das ações cotidianas, dá à expressão teatral um sentido dialético.

A força da gestualidade e da voz grotesca seria a tônica do modo de atuar dos atores dos movimentos de vanguarda da virada do século, o Expressionismo, e depois, o Futurismo, Dadaísmo e Surrealismo. Desde a polêmica montagem de Ubu-rei, de Alfred Jarry, em 1896, os dadaístas, futuristas e surrealistas escandalizariam os ícones tradicionais do teatro. O espírito de escárnio do Futurismo e do Surrealismo, a desintegração da linguagem, a falta de compromisso com a verossimilhança, a explosão da noção de personagem, a fragmentação do espaço e da dramaturgia (Aslan, 1994, p. 91) colocariam em xeque o próprio sentido do teatro. Na prática desmistificadora do espetáculo e na teoria provocadora dos encenadores da vanguarda histórica, o espírito niilista e zombeteiro com que estes artistas tecem suas críticas é muito próximo ao dos bufōes.

O Expressionismo, movimento que floresce a partir de 1910, principalmente na Alemanha, como uma apocalíptica reação de jovens artistas, mediante um mundo desmoronado deixado pela Primeira Guerra Mundial, utilizaria o grotesco para expressar a natureza bestial do homem que aflora sob sua aparência social. O Expressionismo rejeitaria, principalmente, o naturalismo e, assim, traria um teatro que projeta as forças da alma, de modo anarquista e blasfemo que grita violentamente como no célebre quadro de Munch. Os mesmos fantasmas e visões fantásticas do romantismo são retomados e são transformados em estados psíquicos, materializados pelos corpos deformados de personagens e por cenários expressionistas.
O cinema, no desenrolar dos acontecimentos artísticos renovados, abrigaria as mais interessantes inserções destes bufôes soturnos e loucos das telas. Aparentemente saídos de um quadro de Goya, como no exemplo do $\mathrm{Dr}$. Caligari, do diretor Robert Wiene, personagens grotescos habitam cenários que estendem nos ângulos tortuosos os símbolos da deformação psicótica. Esses monstros modernos do cinema alemão seriam vistos de vários ângulos pelos diretores da época e se tornariam ícones da arte cinematográfica deste século, pela forma estilizada e pela atuação grotesca. Podemos assistir, ainda hoje, em cineclubes especializados, às obras exemplares de Murnau ou Fritz Lang.

$\mathrm{Na}$ variada dramaturgia do decorrer do século se pode ver também as múltiplas faces da figura do bufão. Na Itália, o Teatro do Grottesco abordaria o tema com Luigi Chiarelli, Antonelli e Cavacchioli, Fausto Maria Martini, Nicodemi, Rosso di San Secondo e o mais famoso deles, Luigi Pirandello, os quais se fundiam na idéia de que o homem possui uma máscara ou aparência, que lhe permite viver em sociedade, sob a qual se oculta o verdadeiro rosto.

Para outros autores, a bufonaria aparece acentuando o cômico, em outros, o fantástico e o sombrio ou, ainda, desarticulado como em Ionesco, ou existencial como em Beckett. Mas a diversidade de seu ser demonstra em quantas formas ele pode aparecer, se metamorfosear, ou mesmo, se disfarçar.

Às vezes ele aparece como personagem, em outras como uma máscara do ator que traz um espírito inquieto e subtérreo às propostas do artista. Mas grande parte destas formas teatrais, de fato, foi beber na fonte do Teatro de Variedades, no Circo, no Vaudeville, na Commedia Dell'Arte e na Ópera de Pequim, valorizando assim o papel do popular. No artista popular se encontrariam os atributos para garantir aos atores versatilidade, espírito habilidoso, prontidão física e diversão. 


\section{A bufonaria digerida pelo teatro moderno}

Pode-se assim pensar numa retomada do bufão pelo teatro, delineando um percurso da máscara para a sala de espetáculo. Se, às vezes, ele aparece como um personagem da dramaturgia, em outras surge como um procedimento técnico para o ator.

Nas mãos do polêmico encenador russo Meyerhold, o bufão reaparece pelas vias do teatro de feira, da pantomima, do Arlequim da "Commedia Dell'Arte", do teatro de Gozzi e do teatro chinês ("Nô"e "Kabuki") que servem para a elaboração de conceitos fundadores do ator e do seu teatro. A partir das grandes tradiçōes do espetáculo ele dá forma à idéia do "Teatro Teatral".

Meyerhold queria resgatar para o teatro o seu caráter convencional, diáfano e ofensivamente teatral. A sua estética passou por diferentes fases de concepção, mas foram, acima de tudo, a idéia de tirar todo o ilusionismo da relação cena e público, a negação da prioridade do texto e a busca de expressividade do ator, os tópicos centrais da sua teoria e práticas cênicas.

Para conseguir tais objetivos, iria resgatar o grotesco do teatro popular e recomendar sua utilização como um recurso para vivificar o teatro: "O grotesco permite o cotidiano em um plano inédito, o aprofunda a tal ponto que o cotidiano deixa de parecer natural" (Meyerhold, 1986, p. 61).

Com gestos exagerados atenuados, o uso do grotesco não deixaria espaço para a concretude, para a afirmação e para a interpretação verossímil do realismo-naturalismo de Stanislavski. Neste sentido, ele estaria usando na atuação apenas a alusão, a sugestão dos gestos e nunca a reprodução minuciosa da vida. A representação trataria a realidade com estilização.

$\mathrm{O}$ ator grotesco encontraria ainda o seu equivalente no conceito de ator sintético. Este, para Meyerhold, seria um ator que dominaria o corpo com conhecimento profundo do seu aparato biológico. Ele usaria a sua expressividade máxima e deveria saber agir com a argúcia do palhaço, do "jongleur", do acrobata, do cantor e do dançarino.

Meyerhold fala sobre a relação intrínseca entre o sintético e o grotesco. Será sintética, mas não-cumulativa, porque não deverá mostrar tudo, muito menos reproduzir, ilustrar ou explicar. A criação grotesca deverá evidenciar a densidade concreta do real sem referi-la.

O princípio da substituição é fundamental no grotesco. Mesmo quando se toma a realidade como tema, a representação tem que ter algo ao mesmo tempo estranho e familiar. Com isto, o resultado de cada representação alcançaria o seu objetivo somente se fosse capaz de revelar os sentidos ocultos ao espectador. Ao público seria apresentado um mundo palpitante, fremente, emocionante, no qual nenhum elemento teria mais o seu rígido papel institucional.

A interpretação poderia mesclar o cômico e o trágico, como nos desenhos de Goya ou nos contos de Edgar Alan Poe e Hoffmann, num esforço de superar as situações cotidianas. Ele não pretendia desordenar a realidade, utilizando o método do grotesco na encenação, mas, ao contrário, saber reinventá-la naquele espaço cênico restrito e artificial. A cena se tornaria um lugar de "tensões", de contrastes que gerariam um fluxo dinâmico na representação.

$\mathrm{Na}$ encenação de $O$ Inspetor Geral, de Nicolai Gógol, Meyerhold cria um novo gênero cênico, diz Arlete Cavaliere, surgido de suas experiências com a pesquisa dos elementos cômicos que "com suas linhas estéticas deformantes e deformadas, suas proporções aumentadas e suas imagens exageradas e traços distorcidos, aponta uma espécie de bufonaria trágica..." (Cavaliere, 1996, p. 91).

A partir disso, surge um outro ponto fundamental, a composição paradoxal, a qual Meyerhold sugere utilizar nas diferentes estruturas dramáticas. Assim, mesclar um personagem trágico com funções cômicas torna possível a passagem da burla para a tragédia, equilibra os sentidos opostos, inclusive ressaltando a feiúra e impedindo que a beleza se torne sentimental. 
É importante ressaltar o fato de que o grotesco se apresenta, em Meyerhold, não como um estilo, mas como uma técnica. Ele tira o grotesco do estilo e o transforma em procedimento. O grotesco não é o tema, mas sim a contraposição entre elementos sensíveis e perceptíveis.

Para Meyerhold, assim como para Brecht, a figura grotesca do bufão foi resgatada da literatura para os palcos, carregada da inteligente ironia necessária para desmascarar a vida política e social de seu tempo. Nas mãos de Brecht, o nosso farsante reapareceria com os recursos do circo e Cabaret alemão, os quais serviriam sobremodo para restituir o que ele acreditava ser a principal função estética do teatro, a diversão.

Uma diversão de acordo com o seu tempo, que reivindica para o teatro de uma época científica a racionalidade das novas formas tecnológicas, como o cinema e o rádio (Benjamin, 1987, p. 98). O teatro épico de Brecht também teria a forma episódica, permitindo entradas e saídas aos atores e personagens, interrompendo o envolvimento ilusionista que o espetáculo pode produzir nos espectadores. Com o público e artistas em posição de distanciamento, pode-se então reconhecer as situações reais inspiradas na teatralidade da vida.

O teatro não-aristotélico de Brecht, além de colocar o homem comum no centro da dramaturgia, não deve propiciar a catarse nem a empatia diante do herói trágico. Ao contrário, o espectador não se identifica com as personagens, mas as reconhece em suas contradições. Como na técnica do cinema, a cena de Brecht corta, recorta, monta, cola, edita, em processo descontínuo. E o ator, por sua vez, conta, narra e expõe diretamente ao público, combinando acontecimentos em tempos diferentes. O lugar das emoções é reservado ao espectador que, sem os recursos da ilusão cênica, é levado a refletir ativamente sobre o que assiste. A realidade é analisada pelo confronto de idéias opostas, na direção de um teatro dialético.

A redescoberta de Brecht dos valores do velho teatro popular se traduz na produção de uma atuação e dramaturgia "vaudevillenesca", fragmentada e viva como os "números" circenses. O trabalho do ator consiste em contar uma história (fábula) por meio de atitudes gestuais. O gestus, guardada a sua dimensão assaz complexa, indica uma conduta ou atitude social. Ligada ao conteúdo histórico e ideológico marxista, a escritura corporal (feita também de palavras) se constrói a partir de diferentes níveis miméticos, desde um detalhe de movimento de um personagem a um comportamento característico de um grupo. Mais do que isto, o gestus deve revelar as idéias subentendidas nas palavras e acontecimentos. Ações que contradizem os textos produzem fissuras na representação, provocando o efeito de estranhamento e distanciamento essenciais para o teatro épico.

$\mathrm{O}$ ator brechtiano, neste sistema de trabalho, é um enunciador que interage criticamente, a partir do seu ponto de vista, com o do personagem e com o do espectador. Ora afastado ora próximo, o ator representa um elo entre o significado e o significante, entre o real e o simulacro, entre arte e vida. Nesse vaivém, o ator se multiplica transitando entre diferentes gêneros, implícita ou explicitamente, do drama à farsa. Evocando referências reais e corporificando-as em paródias o ator expressa as relaçôes sociais entre os homens.

De certo modo, os fundamentos de Meyerhold ou de Brecht encaminham-se para um teatro que hoje se expande no vigor da linguagem corporal. Sem a ortodoxia ideológica e a dimensão social da gestualidade, o teatro de Jerzy Grotowski, Eugenio Barba, Peter Brook, Ariane Mnouchkine amplia as noçóes corporais para um sentido antropológico ou intercultural. Especialmente nos modos de criação de Tadeusz Kantor vimos desfilar a blasfêmia misturada à mais fina poesia teatral. Com humor e cinismo, Kantor tira da sua memória de criança as personagens mais bizarras das experiências das duas grandes guerras mundiais e da situação política da Polônia.

Como na prática da bufonaria, tanto em Kantor como em Brecht, as histórias tratam de temas sociais, e as sátiras versam sobre o poder, 
a política, a religião, a guerra, a família, os tabus e as diferenças de status. Estas combinações conferem, deste modo, uma tendência crítica ao modo farsesco de atuar.

\section{A experiência da alteridade}

Artistas, vagabundos, ladrōes, loucos e marginais. Corcundas, aleijados, anões, gigantes e monstros completam o grupo de sujeitos excêntricos que desfilam no "bando dos bufōes". $\mathrm{Na}$ fragilidade do mundo particular em que se aglutinam vigora a loucura. Embora exista um grande número de exemplos na literatura de bufōes solitários, eles pertencem a uma massa aparentemente inútil. São, no entanto, o cerne de uma minoria excluída socialmente que mostra o vigor político nas atitudes imprevisíveis.

A esse coletivo pertencem os negros, os gays, as mulheres, as prostitutas, os doentes, os aleijados, os despatriados, os sem-terra, os sem teto e todos aqueles que são inadequados na sociedade. Indiferente à sua adversidade, o "bando" se diverte zombando da hipocrisia e mediocridade humana. Eles se divertem muito satirizando as autoridades. Como na sociedade em que se espelham para debochar, eles são comandados por um chefe, a quem todos se alegram em obedecer. Eles zombam até do "inzombável”: da guerra, da fome do mundo, de Deus (Lecoq, 1997, p. 35).

A ambigüidade da sua figura, portanto, não cessa nas energias que o potencializam, ou no físico que o caracteriza, mas também forra o fundo de suas convicçôes acerca do mundo em que vive. O bufão representa o ser humano em estado bruto - amoral, complexo, múltiplo podendo ser comparado, ao mesmo tempo, ao veneno e à cura. Haja vista que na Idade Média, onde o pensamento se orientava pela ordem divina, era comparável ao diabo pela aparência medonha que em todos provocava asco, medo e riso e, ao mesmo tempo, era tido como um talismã da sorte cuja presença, acreditavam, afastava os males.
Esta figura engloba tantos tipos de riso, com os corpos deformados e deformantes debochando de nós, para se divertir e divertir a nós mesmos, que a sua figura nos causa estranheza. O que esta figura da tradição cômico-popular, presente de maneira tão incerta e ao mesmo tempo tão caricaturizada, pode interessar ao trabalho do ator contemporâneo?

Seja qual for a imagem relacionada a ele que, certamente, todos temos no fundo da nossa memória, sua importância vai muito além da construção de uma personagem histriônica. Mais do que uma máscara entre outras, o bufão é um catalisador de valores e códigos culturais, com capacidade de produzir processos perceptivos em termos especificamente teatrais.

À primeira vista, o Bufão apresenta regras básicas de contracenação, de jogo, de cumplicidade e de prontidão, sem elaborações artísticas mais complexas. Sua principal meta é trazer diversão ao teatro. Somente pelo prazer do jogo ele usa da blasfêmia, que é a mais radical negação da ordem social. Para blasfemar, é preciso que o ator tenha do que blasfemar. Pois quem blasfema não é o bufão, mas o ator que veste a sua máscara. O bufão é o veículo, a forma dissimulada para desfiar a crítica contra nós mesmos, contra a sociedade em que vivemos.

A técnica do Bufão tem como eixo o desenvolvimento da capacidade improvisacional, e tem segredos e regras que atuam numa extensão que vai do farsesco ao trágico. $\mathrm{O}$ corpo deformado constitui-se numa máscara de corpo inteiro, plasmada numa alegoria que implica em inúmeras conotaçôes e cujos sentidos deixam entrever a visão de mundo não só da personagem, mas também do ator. O corpo aleijado, deformado e defeituoso pode ser materializado por um figurino exagerado e descomunal. Mas sem o figurino, o ator pode reconstruir e destruir o comportamento dos homens somente com a força expressiva de seu corpo.

O jogo da máscara oculta uma duplicidade inerente, a do ator e a do personagem, cuja natureza pressupõe a existência de um outro, 
como na discussão amplamente examinada no Paradoxo do Comediante, por Diderot.

A máscara do bufão propõe um outro olhar sobre as relações entre o corpo deformado e o deformante: a noção de alteridade possibilita a coexistência de idéias opostas que, por força das contradições, se anulam. A ambigüidade da máscara expressa esta antítese, criando uma segunda natureza para a personagem, ou para o ator. O grotesco, entretanto, por diversas circunstâncias, tenta fazer coincidir máscara e rosto simultaneamente. Essa oposição entre dois valores, entre duas coisas, produz uma forma nadificante, 5 onde uma nega algo que precisa ser afirmado pela outra. Ou seja, trata-se de uma categoria estética de território irrestrito. ${ }^{6}$

Sendo a paródia a imitação burlesca de uma obra ou de um personagem conta, pelo menos, com duas faces: a máscara real e a máscara da derrisão, ambas situadas na esfera da personagem. A real é a base para a imitação da outra que é a alegórica, estilizada (Martin, 1985, p. 27). Uma face serve de referência para o descortino que se processa com a outra. Sendo assim, a máscara do ator (em situação de performance) é a face matriz, a que empresta sua plástica para o desdobramento das outras duas máscaras. Dessa maneira, o ator, como o sujeito da representação, empresta seu corpo ao deformado, o bufão; o qual, no exercício da paródia, alude a um terceiro componente, o deformante, ou o referente.

Esta triplicidade na atuação é a base do jogo que leva o ator a interagir com as diferentes camadas de representação. Alternando entre o tempo presente e passado, a presença do ator alude a algo ou a alguém para assim compor a sua performance. No domínio destas relações intersubjetivas, pode-se pensar ainda que a arte do bufão consiste em estabelecer diálogos corpóreos, profanos e risíveis, entre o real e o virtual, entre si e com os outros.

A multiplicidade dos diálogos se dá sempre com os "outros", com o corpo do outro, centrando-se numa experiência de alteridade. Quando ele imita um gesto ou uma ação ele expõe o ridículo do outro e dele mesmo. O seu corpo, desta forma, representa outros corpos, colocando a sua monstruosidade em cena. $\mathrm{O}$ ator consegue tirar daí a sua força de expressão do que é disforme. E com um humor demoníaco, ele debocha por prazer, por pura diversão. Ele usa da ironia, que é a mais inteligente e potente arma, para denunciar as diferentes faces da maldade dos homens.

Os múltiplos discursos do bufão funcionam como uma colagem. Nele mesmo cruzamse distintas vozes e seres ficcionais (textos sérios e jocosos; humano e fantástico). Torna-se possível reunir, também, várias referências estéticas e poéticas (tragédia e comédia; o sentimental e a grosseria) dentro de um mesmo processo de atuação.

Pode-se ainda pensar em relações entre "personas" no lugar de personagens. Pensando assim, leva-se em conta que a paródia não trabalha com a produção de mimese no sentido clássico, mas sim com uma espécie de captura física de imagens, figurações ou evocações. $\mathrm{O}$ sentido de personagem do drama, de verossimi-

5 Conceito desenvolvido por Jacó Guinsburg, durante a orientação da tese de doutorado desta autora. Um exemplo de forma nadificante está em Dioniso, que funde em seu mito o trágico e o cômico.

6 No texto para Bufôes, de Phillipe Gaulier, chamado "Celui-ci n’est pas mon fils", a Santíssima Trindade - o Pai, o Filho e o Espírito Santo - são transformados em Bufōes. Na associação de Deus com um ser sanguinário e cruel, infantil e caprichoso, na humanização da criatura divina, novamente o cômico e o trágico se fundem, o que implica em uma forma nadificante, já que se perde o sentido original das divindades para exprimir uma realidade amoral, ambígua e estranha. Esse texto tem uma tradução portuguesa feita por Fernando Kinas, que também é diretor e professor de teatro. 
lhança e de identificação, se acontece, se dá no resgate do modelo que será "destruído" pela derrisão.

Desta forma, ser bufão envolve as distintas camadas da representação mimética, vista aqui como uma constelação de referências e espaços da imaginação. Trata-se ainda de reunir tais espaços e contradições em um só corpo, criando uma miríade de tensões que modelam de modo peculiar este comportamento cênico. Nesta sua interdiscursividade corporal o bufão tem que preservar a humanidade das imitações burlescas, extraindo da realidade a sua criatividade. Quem o assiste deve reconhecer a realidade que está sendo burlada.

O que conta para o bufão é o diálogo que ele estabelece com o público e, mais especificamente, com o que Phillipe Gaulier chama de "bastardo" - o alvo das denúncias e da zombaria. O sujeito "bufonável" ganha dimensões e modos extravagantes sem perder a referência do real. Essa é uma forma de ganhar a cumplicidade da platéia, que em essência é o alimento do seu humor. Se o espectador se diverte, mesmo que tire o prazer de rir da própria desgraça, isto quer dizer que a "temperatura" da atuação está no ponto ideal e que o ator pode seguir em frente. Em estado quase permanente de ebulição, a improvisação se vale da energia do "aqui e agora”. O jogo do ator, pelo menos, deve aparentar o mesmo frescor.

A esse ofício tão antigo se designou uma máscara, e nem sempre, na sua longa história, o ator e mesmo o espectador conseguiram delimitar fronteiras entre o momento em que começa e em que termina a representação. A dupla face de sua expressão já era uma espécie de estigma para o ator bufo no mundo medievo e renascentista, cuja presença tragicômica se fazia presente em todos os momentos de sua vida. Não é possível imaginar um bobo da corte sem as suas vestimentas, andando como um ator de folga pelo palácio. Neste sentido, a atuação do bufão se aproxima do sentido de performance, no ponto em que tal manifestação implica em esfumaçamento das noções de vida e representação.
A performance, em seus atributos artísticos, se caracteriza pela transformação do corpo em signo além da presentificação do ato. O que se vê é de forma simplificada, é uma imagem distorcida do mundo real, uma parte do todo que se organiza nas açôes. $\mathrm{O}$ gesto e a movimentação, deliberadamente, artificiais e exagerados, tornam-se uma narrativa que mistura tempos, espaços e máscaras. A linguagem corporal e vocal do bufão, nesta inter-relação, evoca imagens visíveis e conhecidas. Além disto, tais recursos técnicos nos fazem recordar de certas imagens temidas, aquelas que se encontram ocultas de nós mesmos.

Há uma espécie de negação da interpretação de uma personagem no sentido tradicional, em favor de uma dilatação das energias expressivas pessoais do ator. Há uma liberdade, neste jogo, de romper com qualquer sistema de interpretação. Evidente que nem questionamos o fato de que este jogo não seja uma representação, visto que não é uma ação do cotidiano. Isto acontece devido a um embaralhamento das referências, peculiar do jogo, que faz quem assiste confundir a verdade com a representação.

Faz-se necessário um esforço da memória associativa para desencadear a ação da paródia. Gaulier sempre diz que tem de se trabalhar com a lembrança de uma grande diversão. Somente assim, com este estoque de memória, a referência real do parodiado será base para uma representação "turbinada" que se manifesta em uma potencialização de energias. Como na caricatura, entretanto, o resultado da expressão será sintético, já que não necessita mais do que quatro ou cinco características para produzir a imitação burlesca (Lecoq, 1998, p. 45).

Vale dizer que o jogo farsesco do bufão tem, como as suas origens carnavalescas, múltiplas significações, mas pouco necessita, além do ator, para exercitar a sua teatralidade. A rigor, o ator precisa no máximo de alguns acessórios que ampliam o jogo. O bufão é imagem, é visual. Tem que buscar equivalentes na representação e não na semelhança. E encontrar os símbolos justos no corpo e na imagem para desvendar as verdades. 
No Brasil contemporâneo, este "trickster", insolente e zombeteiro, se revela na mescla inteligente da personalidade e do teatro de José Celso Martinez Correa, de Gerald Thomas e de Cacá Rosset. A evocação do espírito bufonesco não se limita a um modo de atuação ou de encenar, mas tem relação com o artista que toma para si o comportamento combativo e performático deste ser conhecido pela popularidade e irreverência.

Trabalhar com o bufão sem dúvida é assumir os riscos da experiência teatral. Sob outro prisma, pode oferecer um material específico para o trabalho do ator, o qual abre, por sua vez um plano horizontal de possibilidades. Ele pode representar uma dimensão original para a formação e para as práticas do ator. Sem receio da linguagem "baixa" para tratar dos temas "altos", o trabalho do ator rompe os limites da elegância e do sentimentalismo que parecem envolver toda a filosofia do teatro sério. Sendo assim, a experiência com o bufão é ir contra o "politicamente correto” da representação teatral. É mesmo eleger essa incorreção como maneira de atuar.

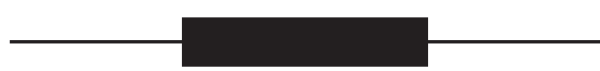

\section{Referências bibliográficas}

ASLAN, Odette. O Ator no século XX. São Paulo: Perspectiva, 1994.

BENJAMIN, Walter. "O que é teatro épico? Um estudo sobre Brecht". In: Magia e técnica, arte e politica. Obras escolhidas Volume I. Trad. de Sergio Paulo Rouanet. São Paulo: Brasiliense, 1987.

BAKHTIN, Mikhail. Problemas da poética de Dostoievski. Rio de Janeiro: Ed. Forense-Universitária, 1981.

BERGSON, Henri. O riso. Ensaio sobre a significação do cômico. Rio de Janeiro: Zahar, 1983.

CAVALIERE, Arlete. O inspetor geral de Gógol/Meyerhold. São Paulo: Perspectiva, 1996.

CLASTRES, Pierre. A sociedade sem classes. Pesquisa de antropologia politica. Rio de Janeiro: Francisco Alves, 1978.

DUVIGNAU, Jean. Rire et Après. Essai sur le comique. Paris: Descée de Brouwer, 1999.

GAULIER, Phillipe. “Celui-ci n'est pas mon fils”. Trad. de Fernando Kinas. São Paulo: não-editado.

GAZEAU, A. Historias de bufones. Madrid: Miraguano, 1995.

LECOQ, Jacques. Les Corps Poétique. Un enseignement de la création théatrale. Paris: Actes SudPapiers, 1997.

MACEDO, José Rivair. Riso, cultura e sociedade na Idade Média. Porto Alegre/São Paulo: Editora da Universidade -UFRGS/UNESP, 2000.

MARTIN, Serge. “Le fou roi des Theatres”. In: Buffoneries, n. 13/14, Paris: Contrastes, 1985. 
MEYERHOLD, Vsevolod. Teoria Teatral. Madrid: Fundamentos, 1986.

NIETZSCHE, Friedrich. O nascimento da tragédia ou helenismo e pessimismo. Tradução, notas e pósfácio de J. Guinsburg. São Paulo: Perspectiva, 1992.

PAVIS, Patrice. "Mise au point sur le Gestus"; "Le gestus brechtien et ses avatars dans la mise en scène contemporaine". In: Vers une théorie de la pratique théâtrale. Voix et images de la scène 3. Paris: Presses Universitaires du Septentrion, 2000, p. 67-93. 